TITLE:

\title{
The Reaction of Ylides with Halocarbenes
}

\author{
$\operatorname{AUTHOR}(\mathrm{S})$ :
}

Okano, Masaya; Ito, Yoshihiko; Oda, Ryohei

\section{CITATION:}

Okano, Masaya ...[et al]. The Reaction of Ylides with Halocarbenes. Bulletin of the Institute for Chemical Research, Kyoto University 1964, 42(4): 217-220

\section{ISSUE DATE:}

1964-08-25

URL:

http://hdl.handle.net/2433/76027

RIGHT: 


\title{
The Reaction of Ylides with Halocarbenes*
}

\author{
Masaya Orano, Yoshihiko ITo and Ryohei OdA** \\ (Oda Laboratory)
}

Received April 30, 1964

\begin{abstract}
A new method of haloölefin formation has been found which involves an electrophilic attack by halocarbenes on the nucleophilic carbon of $\mathrm{P}$ - and S-ylides.
\end{abstract}

The increasing interest has been shown in the chemistry of carbenes, especially on the electronic state of the divalent carbon species. As far as halocarbenes such as dichloro- and dibromocarbenes are concerned, it is apparent that they are in the singlet state at usual reaction conditions. Namely, the electrophilic nature of these carbenes is substantiated in their reactions with olefins, amines, alkoxides, triphenylphosphine, and sodiomalonates ${ }^{1}$.

The Wittig's discovery excited considerable attention to the chemistry of P-and S-ylides. Some similar reactions with epoxides, Schiff bases, $\alpha, \beta$-unsaturated esters, and nitrosobenzene have also been reported ${ }^{23}$. It seems that these reactions, including the Wittig reaction, involve an attack by electrophilic carbon or nitrogen of these reagents on the negatively-charged carbon of P-or S-ylides. Recently, this has been confirmed kinetically in the Wittig reaction of a carbomethoxy-P-ylide with a series of aromatic aldehydes ${ }^{3}$.

Based on the fact that the electronic character of ylides is opposite to that of halocarbenes, the reaction of these two reagents was examined expecting the formation of haloölefins as illustrated:

$$
\mathrm{RR}^{\prime} \stackrel{\ominus}{\mathrm{C}}-\oplus_{\mathrm{PR}}^{\prime \prime}+: \mathrm{CXY} \longrightarrow \mathrm{RR} \mathrm{R}^{\prime} \mathrm{C}=\mathrm{CXY}+\mathrm{PR}_{3}^{\prime \prime},
$$

where $\mathrm{X}$ and/or $\mathrm{Y}$ are halogen atoms.

The following $\mathrm{P}$ - and S-ylides as substrates were prepared by the literature procedure. This class of ylides belongs to the resonance-stabilized type. Ttriphenylphosphonium cyclopentadienylide (PPP), triphenylphosphonium fluorenylide (PPF), tri-n-butylphosphonium fluorenylide (BPF), dimethylsulfonium fluorenylide (MSF), carbethoxymethylenetriphenylphosphorane (PPCM), $\alpha$-carbethoxyethylidenetriphenylphosphorane (PPCE), $\alpha$-carbethoxybenzylidenetriphenylphosphorane (PPCB), dicarbethoxymethylenetriphenylphosphorane (PPDC), and dicyanomethylenetriphenylphosphorane (PPDN). Dichlorocarbene was generated in situ from chloroform and potassium $t$-butoxide, or by refluxing sodium trichloroacetate in aprotic solvents. Similarly, bromoform, dichlorofuoromethane, and benzal chloride were used as the precursor of dibromo-, chlorofluoro-, and phenylchloro-carbenes, respectively.

\footnotetext{
* A preliminary report of a part of this work has been published in Tetrahedron Letters, 7 (1964).

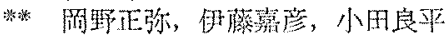


Masaya OKano, Yoshihiko ITo and Ryohei ODA

Table 1 Formation of $\alpha$-haloölefins from ylides and halocarbenes.

\begin{tabular}{|c|c|c|c|c|}
\hline $\begin{array}{l}\text { Run } \\
\text { No. }\end{array}$ & Ylide & $\begin{array}{l}\text { Source of } \\
\text { carbene }\end{array}$ & $\begin{array}{l}\text { Reaction temp. } \\
\text { and time }\end{array}$ & $\begin{array}{l}\text { Product } \\
\text { M.p. or b.p., yielda }\end{array}$ \\
\hline 1 & PPP & $\mathrm{CHCl}_{3}$ & $\begin{array}{l}10-15^{\circ} \mathrm{C} \\
4 \text { hrs. }\end{array}$ & Unreacted \\
\hline 2 & PPP & $\mathrm{C}_{6} \mathrm{H}_{5} \mathrm{CHCl}_{2}$ & $\begin{array}{l}70-75^{\circ} \mathrm{C} \\
12 \mathrm{hrs}\end{array}$ & Unreacted \\
\hline 3 & $\mathrm{PPF}$ & $\mathrm{CHCl}_{2} \mathrm{~F}$ & $\begin{array}{l}10-15^{\circ} \mathrm{C} \\
4 \mathrm{hrs}\end{array}$ & $\begin{array}{l}\text { 9-(Chlorofluoromethylene)fluorene } \\
\text { m.p. } 76-77^{\circ} \mathrm{Cb}, 21 \%(43 \%)\end{array}$ \\
\hline 4 & PPF & $\mathrm{CHCl}_{3}$ & $\begin{array}{l}10-15^{\circ} \mathrm{C} \\
4 \mathrm{hrs}\end{array}$ & $\begin{array}{l}\text { 9-(Dichloromethylene)fluorene } \\
\text { m.p. } 129-130^{\circ} \mathrm{Cc}, 44 \%(50 \%)\end{array}$ \\
\hline 5 & PPF & $\mathrm{CCl}_{3} \mathrm{COONa}$ & $\begin{array}{l}75-80^{\circ} \mathrm{C} \\
12 \mathrm{hrs}\end{array}$ & $\begin{array}{l}\text { 9-(Dichloromethylene)fluorene } \\
\text { m.p. } 129-130^{\circ} \mathrm{Cc}, 41 \%\end{array}$ \\
\hline 6 & PPF & $\mathrm{C}_{6} \mathrm{H}_{5} \mathrm{CHCl}_{2}$ & $\begin{array}{l}70-75^{\circ} \mathrm{C} \\
12 \text { hrs. }\end{array}$ & $\begin{array}{l}\text { 9-( }(\alpha \text {-Chlorobenzylidene)fluorene } \\
\text { m.p. } 119-120^{\circ} \mathrm{Cd}, 59 \%(84 \%)\end{array}$ \\
\hline 7 & $\mathrm{BPF}$ & $\mathrm{C}_{6} \mathrm{H}_{5} \mathrm{CHCl}_{2}$ & $\begin{array}{l}70-75^{\circ} \mathrm{C} \\
12 \mathrm{hrs}\end{array}$ & $\begin{array}{l}\text { 9-( } \alpha \text {-Chlorobenzylidene }) \text { fluorene } \\
\text { m.p. } 119-120^{\circ} \mathrm{Cd}, 77 \%\end{array}$ \\
\hline 8 & MSF & $\mathrm{CHCl}_{3}$ & $\begin{array}{l}10-15^{\circ} \mathrm{C} \\
4 \mathrm{hrs}\end{array}$ & $\begin{array}{l}\text { 9-(Dichloromethylene)fluorene } \\
\text { m.p. } 129-130^{\circ} \mathrm{Cc}, 9 \%\end{array}$ \\
\hline 9 & MSF & $\mathrm{CHBr}_{2}$ & $\begin{array}{l}10-15^{\circ} \mathrm{C} \\
4 \text { hrs. }\end{array}$ & $\begin{array}{l}\text { 9-(Dibromomethylene)fluorene } \\
\text { m.p. } 122-123^{\circ} \mathrm{Ce}, 2 \%\end{array}$ \\
\hline 10 & PPCM & $\mathrm{CHCl}_{3}$ & $\begin{array}{l}10-15^{\circ} \mathrm{C} \\
4 \mathrm{hrs}\end{array}$ & $\begin{array}{l}\text { Ethyl } \beta, \beta \text {-dichloroacrylate } \\
\text { b.p. } 78-82^{\circ} \mathrm{C} / 43 \mathrm{~mm} .\end{array}$ \\
\hline 11 & PPCM & $\mathrm{CCl}_{3} \mathrm{COONa}$ & $\begin{array}{l}75-80^{\circ} \mathrm{C} \\
12 \text { hrs. }\end{array}$ & $\begin{array}{l}\text { Ethyl } \beta, \beta \text {-dichloroacrylate } \\
\text { b.p. } 78-82^{\circ} \mathrm{C} / 43 \mathrm{~mm} .\end{array}$ \\
\hline 12 & PPCM & $\mathrm{C}_{6} \mathrm{H}_{5} \mathrm{CHCl}_{2}$ & $\begin{array}{l}75-80^{\circ} \mathrm{C} \\
15 \text { hrs. }\end{array}$ & $\begin{array}{l}\text { Ethyl trans- } \beta \text {-chlorocinnamate } \\
\text { b.p. } 95-115^{\circ} \mathrm{C} / 3 \mathrm{~mm}, \mathrm{~g}, 25 \% \mathrm{~h}\end{array}$ \\
\hline 13 & PPCE & $\mathrm{CCl}_{3} \mathrm{COONa}$ & $\begin{array}{l}75-80^{\circ} \mathrm{C} \\
12 \text { hrs. }\end{array}$ & $\begin{array}{l}\text { Ethyl } \beta, \beta \text {-dichloromethacrylate } \\
\text { b.p. } 90-92^{\circ} \mathrm{C} / 43 \mathrm{~mm} ., 45 \%\end{array}$ \\
\hline 14 & $\mathrm{PPCB}$ & $\mathrm{CCl}_{3} \mathrm{COONa}$ & $\begin{array}{l}75-80^{\circ} \mathrm{C} \\
12 \text { hrs. }\end{array}$ & $\begin{array}{l}\text { Ethyl } \beta, \beta \text {-dichloro- } \alpha \text {-phenylacrylate } \\
\text { b.p. } 112-114^{\circ} \mathrm{C} / 2 \mathrm{~mm} \text {.j, } 38 \%(46 \%)\end{array}$ \\
\hline 15 & PPDC & $\mathrm{CCl}_{3} \mathrm{COONa}$ & $\begin{array}{l}75-80^{\circ} \mathrm{C} \\
12 \text { hrs. }\end{array}$ & $\begin{array}{l}\text { Ethyl dichloromethylenemalonate } \\
\text { b.p. } 95-100^{\circ} \mathrm{C} / 8 \mathrm{~mm} . \mathrm{k}, 7 \%(16 \%)\end{array}$ \\
\hline 16 & PPDN & $\mathrm{CCl}_{3} \mathrm{COONa}$ & $\begin{array}{l}75-80^{\circ} \mathrm{C} \\
12 \text { hrs. }\end{array}$ & $\begin{array}{l}\text { Dichlorovinylidene cyanide } \\
\text { m.p. } 65^{\circ} \mathrm{Cl}^{1}, 5 \%\end{array}$ \\
\hline
\end{tabular}

a. The figures in parenthses indicate conversions based on consumed ylides.

b. Reported m.p. $75-80^{\circ} \mathrm{C}$ (Ref. 11).

c. Reported m,p. $132^{\circ} \mathrm{C}$ (Ref. 12).

d. Reported m.p. $120-121^{\circ} \mathrm{C}$ (Ref. 12).

e. Reported m.p. $131-132^{\circ} \mathrm{C}$ (Ref. 11).

f. Reported b.p. $173-175^{\circ} \mathrm{C}$ (Ref. 13).

g. Reported b.p. $265^{\circ} \mathrm{C}$ (Ref. 14).

h. This value was determined by v.p.c. analysis.

i. A new compound. Anal. Calcd. for $\mathrm{C}_{6} \mathrm{H}_{8} \mathrm{O}_{2} \mathrm{Cl}_{2} ; \mathrm{C}, 39.37 ; \mathrm{H}, 4.41$; Found; C, 39.75; H, 4.53.

j. A new compound. Anal. Cadlc. for $\mathrm{C}_{11} \mathrm{H}_{10} \mathrm{O}_{2} \mathrm{Cl}_{2} ; \mathrm{C}, 53,90 ; \mathrm{H}, 4.11$. Fouhd; C, 54.32; H, 4.28 .

k. A new compound. Anal. Caled. for $\mathrm{C}_{8} \mathrm{H}_{10} \mathrm{O}_{4} \mathrm{Cl}_{2} ; \mathrm{C}, 39.86 ; \mathrm{H}, 4.18$. Found; C, 39.49; H. 4.44.

1. Reported m.p. $63-64^{\circ} \mathrm{C}$ (Ref. 15).

Generally, a mixture of ylides and potassium $t$-butoxide was treated with halforms in benzene for $4 \mathrm{hrs}$. at $10-15^{\circ} \mathrm{C}$. The reaction with benzal chloride, however, was conducted for $12 \mathrm{hrs}$. at $70-75^{\circ} \mathrm{C}$. When sodium trichloroacetate was used as a source of dichlorocarbene, the reaction was carried out in diglyme or dioxane for $12 \mathrm{hrs}$. at $70-80^{\circ} \mathrm{C}$. All results are summarized in Table 1 . No attempt was made to optimize the yields by variation in reaction conditions, so that it is highly probable that the 
yields can be somewhat improved.

The identifications of haloölefins obtained were made by appearance of conjugated $\mathrm{C}=\mathrm{C}$ bands (near $1600 \mathrm{~cm}^{-1}$ ), by comparison of their melting or boiling points with those in literatures, and by their elementary analyses.

The reaction was accompanied, more or less, with tar formation, as in cases of other reactions which proceed through the intermediate formation of carbenes. The yields were generally not so high, and the unreacted ylides could not be recovered except for a few cases.

When PPP was allowed to react with halocarbenes, no reaction was observed and good recoveries of the ylide were made. However, the fluorene analogue, PPF, afforded the expected haloölefins with no difficulty. Such difference in reactivity is also recognized in the Wittig reaction ${ }^{43}$. The reactive BPF showed a higher yield. In the reaction of PPCMI with halocarbenes, the yields were lower than expected, especially in basic media. This may be ascribed to in part subsequent side-reactions of the obtained product ( $\alpha, \beta$-unsaturated carbonyl compounds) with some nucleophilic species. In the case of MSF, the results were disappointing owing to its unusual instability.

The reaction with benzal chloride showed generally better results than that with chloroform or sodium trichloroacetate. Since phenylchlorocarbene seems to be less reactive than dichlorocarbene in electrophilic character, this would imply that the concentration of intermediate phenylchlorocarbene is larger than that of dichlorocarbene and/or that, in the former reaction, the stabilization of the transition state for the step leading haloölefin by overlap of the $\pi$-orbitals of the phenyl group with those of the incipient double bond results in the rate acceleration. More quantitative experiments would be necessary before the problem is throughly discussed.

\section{EXPERIMENTAL}

Synthesis of ylides. All ylides were prepared by procedures previously described in literatures. The following constants were observed. PPP, ${ }^{57}$ m.p. $229-230^{\circ} \mathrm{C}$; $\mathrm{PPF}^{6)}$, m.p. $253^{\circ} \mathrm{C}$; BPF, ${ }^{7)}$ m.p. $123-124^{\circ} \mathrm{C}$; $\mathrm{MSF}^{8)}$, m.p. $75^{\circ} \mathrm{C}$ (decomp.); PPCM ${ }^{9)}$, m.p. $123-124^{\circ} \mathrm{C}^{*}$; PPCE, ${ }^{97}$ m.p. $156-157^{\circ} \mathrm{C}$; PPCB, ${ }^{* * * * 6}$ m.p. $134.5-135.5^{\circ} \mathrm{C}$; $\mathrm{PPDC}^{10)}$, m.p. $106-107^{\circ} \mathrm{C}$; PPDN, ${ }^{10>}$ m.p. $187-188^{\circ} \mathrm{C}$.

Reaction of ylides with halocarbenes. Typical examples are given below.

(a) 9-(Dichloromethylene)fluorene. (i) From PPF and sodium trichloroacetate. -Under nitrogen atomosphere, a mixture of $5.5 \mathrm{~g}$. (0.013 mole) of PPF, $10.0 \mathrm{~g}$. (0.054 mole) of sodium trichloroacetate in $120 \mathrm{ml}$. of diglyme was heated at $75-80^{\circ} \mathrm{C}$ for $12 \mathrm{hrs}$. with stirring. The reaction mixture became brown accompaning the evolution of carbon dioxide. After removal of inogranic material by filtration, digylme was evaporated in vacuo. A benzene solution of the residue was washed with $5 \%$ hydrochloric acid and water, successively, and then dried. Distillation of benzene gave $1.3 \mathrm{~g} .(41 \%)$ of crude 9 -(dicholormethylen)fluorene, and recrystallisation ftom ethanol gave the pure product as light yellow needles, m.p. $130-131^{\circ} \mathrm{C}$. (ii) From MSF and

* The reported value is 7 degrees lower than this.

*** A new ylide. Anal. Calcd. for $\mathrm{C}_{28} \mathrm{H}_{25} \mathrm{O}_{2} \mathrm{P} ; \mathrm{C}, 79.23 ; \mathrm{H}, 5.94$. Found; C, 79.34; H, 6.02. 
chloroform.-Into a stirred mixture of $5.0 \mathrm{~g} \cdot(0.022 \mathrm{~mole})$ of MSF, $11.2 \mathrm{~g} \cdot(0.10 \mathrm{~mole})$ of potassium $t$-butoxide and $70 \mathrm{ml}$. of benzene, $8.0 \mathrm{~g}$. (0.07 mole) of chloroform was added dropwise at $10-15^{\circ} \mathrm{C}$ over a period of ca. 40 mins, under stream of nitrogen. Stirring was continued for additional $3 \mathrm{hrs}$, at room temperature. The reaction mixture was washed with water, dried, and the solvent was evaporated in vacuo. The tar-like residue was extracted with three $50 \mathrm{ml}$. portions of hot ethanol. The combined extracts were treated with Norit, and the alcohol was evaporated to dryness. Recrystallisation of the resulting solid $(0.5 \mathrm{~g} ., 9 \%)$ from ethanol afforded the pure olefin, m.p. $129-130^{\circ} \mathrm{C}$.

(b) 9-( $\alpha$-Chlorobenzylidene) fluorene. From BPF and benzal chloride.-A mixture of $9.0 \mathrm{~g}$. (0.025 mole) of BPF, $14.0 \mathrm{~g}$. $(0.087 \mathrm{~mole})$ of benzal chloride, $11.2 \mathrm{~g}$. $(0.10 \mathrm{~mole})$ of potassium $t$-butoxide and $200 \mathrm{ml}$. of benzene was stirred at $75-80^{\circ} \mathrm{C}$ for $12 \mathrm{hrs}$. under nitrogen atomosphere. After removal of inorganic substance by filtration, the organic layer was concentrated in vacuo. The residue thus obtained was extracted with ethanol. Evaporation of ethanol yielded $5.5 \mathrm{~g} .(77 \%)$ of crude 9- $(\alpha$-chlorobenzylidene $)$ fluorene. The pure product, m.p. $119-120^{\circ} \mathrm{C}$, was obtained as yellow plates after a recrystallization from ethanol.

(c) Ethyl $\beta, \beta$-dichloro- $\alpha$-phenylacrylate. From PPCB and sodium trichloroacetate. -A mixture of $11.0 \mathrm{~g}$. (0.026 mole) of PPCB, $21.0 \mathrm{~g}$. (0.105 mole) of sodium trichloroacetate and $300 \mathrm{ml}$. of dioxane was stirred at $75-80^{\circ} \mathrm{C}$ for $12 \mathrm{hrs}$. under stream of nitrogen. After evaporation of dioxane, a benzene solution of the residue was washed with water, $5 \%$ hydrobromic acid, and water, successively, and then dried. When the combined aqueous layer was made basic with aqueous sodium hydroxide, $2.0 \mathrm{~g}$. of the unchanged ylide was recovered. On the other hand, the organic layer was concentrated, and the residue was reextracted with ca. $100 \mathrm{ml}$. of petroleum ether to remove a tarry by-product. Then the solvent was distilled off, and the resulting liquid was fractionated under reduced pressure to give 2.4 g. (38\%) of the expected ester, b.p. 112 $114^{\circ} \mathrm{C}(2 \mathrm{~mm}$.).

\section{REFERENCES}

(1) (a) W. Kirmse, Angezw. Chem., 73, 161 (1961). (b) J. Hine, "Physical Org. Chem.," 2nd Ed. p. 488, McGraw-Hill, New York (1962). (c) A.P. Krapcho, J. Org. Chem., 27, 2375, 3096 (1962).

(2) A general review is presented in M. Okano, Yuki Gosei Kagaku Kyokaishi, 22, 105 (1964).

(3) A. J. Speziale and D. E. Bissing, J. Am. Chem. Soc., 85, 3878 (1963).

(4) A. W. Johnson, J. Org. Chem., 24, 282 (1959).

(5) F. Ramirez and S. Levy, J, Am. Chem. Soc., 79, 67 (1957).

(6) L. A. Pinck and G. E. Hilbert, J. Am. Chem. Soc., 69, 723 (1947).

(7) A. W. Johnson and R. B. LaCount, Tetrahedron, 9, 130 (1960).

(8) C. K. Ingold and J. A. Jessop, J. Chem. Soc., 713 (1930).

(9) M. Montavon et al, Helv. Chim. Acta, 40, 1248 (1957).

(10) L. Horner and H. Oediger, Chem. Ber., 91, 437 (1958).

(11) H. Reimlinger, Chem. Ber., 97, 339 (1964).

(12) H. Staudinger and J. Siegwart, Helv. Chim. Acta, 3, 847 (1920).

(13) O. Wallach, Anu., 193, 22 (1878).

(14) T. C. James, J. Chem. Soc., 99, 1626 (1911).

(15) A. E. Ardis, U. S. P., 2,774,783 (1956) [Chem. Abst., 51, 11373 (1957)]. 